\title{
"Rent a mom" and other services: markets, meanings and emotions
}

\section{Arlie Russell Hochschild}

Sociology Department, University of California, Berkeley, California 94720, USA

E-mail: ahochsch@berkeley.edu

\begin{abstract}
In this essay, the author explores the impact of commercialisation on emotional life. She considers three approaches to the topic - theories of modernisation, of cultural variation and of capitalist encroachment. Drawing elements from each, she outlines what amounts to a preface to a sociology of emotions approach to commercialisation.
\end{abstract}

Keywords: commodification; emotions; feeling rules; market.

Reference to this paper should be made as follows: Hochschild, A.R. (2005) “ "Rent a mom” and other services: markets, meanings and emotions’, Int. J. Work Organisation and Emotion, Vol. 1, No. 1, pp.74-86.

Biographical notes: Arlie Russell Hochschild is a Professor of Sociology at the University of California, Berkeley. Among her books are The Managed Heart, The Commercialisation of Intimate Life and, (co-edited with Barbara Ehrenreich) Global Woman: Nannies, Maids and Sex Workers in the New Economy.

\section{Introduction}

In an interview with a working mother shortly after her brother and his family paid a week’s visit, she told me:

“ I wanted to give them a good time - my brother, his wife, their two kids, who are 8 and 10. I cooked them nice lasagnas and some great soups. I got out games for the kids. But it rained the whole time they stayed with us and the kids got bored. My brother and his wife didn't help much with the dishes. They didn't say thank you. They just took me for granted. And I had my own kids and husband to think about. I had to ask myself what did they think I am - a bed and breakfast?”

Visits can be hard on those visited. But if we compare a 'way of speaking' common in the USA of the 1950s, there seems something new in this woman's complaint. Envisioning herself at first, perhaps, as a beloved hostess to her kin, she discovers herself to be an invisible drone, not paid for her troubles. She is in a world of kin which sees itself outside the marketplace, but is already inside it (Hyde, 1983; Mauss, 1967). She compares what she does feel - unappreciated as a sister - with what she would feel - compensated as a worker. She is 'listening through the wall' between market and non-market life.

\section{Listening through, borrowing across, and jumping over the wall between market and non-market life}

This essay adds to the ongoing conversation an invitation to explore the very medium in which we swim - as workers, as customers, as friends, lovers and family - the market. It is an invitation to conceptualise the market as a theatre of organisations and emotions and to reflect on the market's daily impact on our emotional lives. What if it were true, I'd like to ask, that we were not out of the market in private life and not always in it at the workplace and mall? What if there were a larger machine - let us call it capitalism - which has its own relationship to our feelings in all these arenas? If this were true, how would we then think about personal feelings?

This essay draws on recent interviews with US working parents who hire service providers, with the service workers hired - daycare workers, elder care workers, nannies, wedding planners, family photo album assemblers and funeral service workers. I've also interviewed workers with jobs that might seem to be on the 
edge of commercial culture, with such titles as 'rent a dad', 'rent-a-brother', and 'rent a mom'. How do we say, 'I love you' through, around and over the wall? How do we consult our feelings to gauge the meaning of gestures filtered through the market? Did a gesture of love seem too little, too standardised, too commercial? Or did it seem real or real enough? How do we codify our feelings so as to see in them answers to these questions?

Normally, we imagine an impermeable wall between market and non-market life, home our haven from a heartless market world, in the words of Christopher Lasch (1977). We also assume that the wall between the two has one, fixed, and agreed-upon meaning. But as Viviana Zelizer has shown, money - one aspect of market life - can have many meanings (1994). Moreover, especially today this wall is highly permeable, the object of cultural belief and strong emotion. Indeed, people who pay for care services (two job couples, for example), those who provide services (childcare, care for the elderly workers, for example), and those who are cared for (children and elderly, for example) all manage their emotions in accordance with their relationship to 'the wall'.

We not only listen through the wall; we borrow over it as well. Borrowing rhetoric from work to apply to home, one plant shift supervisor I interviewed for The Time Bind, a study of home and workplace cultures, expressed hope that his family would be a good 'production team' (Hochschild, 1997, p.114). Another described his wife as his 'best customer'. Going the other way, companies often describe themselves as 'like a family'. Advertisements for at-home services, on which my current research focuses, often offer home-like qualities. One ad posted on the internet by someone looking for a home helper said he or she was looking for 'another member of the family'. In another internet ad a woman searching for a job in eldercare, offered to 'spend quality time with your grandmother'. But for whom is this quality time (Zelizer, 2000)?

We also jump over the wall as well. One woman I interviewed ran a business called 'Rent-A-Mom'. For a divorced former homemaker what began as a complaint against an ungrateful husband ended up as an estrangement from him, and from her unpaid role of housewife, the rhetoric of which she took with her to the marketplace. When I asked her how she came to call her business 'Rent a Mom', she answered:

“ I was married for twelve years and I washed, cooked, and raised my children and a garden. But my husband didn't notice much. He thought the only contribution that mattered was his - earning money.

So after we divorced I figured I might as well get paid for all the things I used to do for free.”

Through the name 'Rent a Mom', she was in a sense, stating her worth at home as a price in the marketplace. She jumped over the wall, even as others, in their quest for meaning, jump back.

Over the last 15 years the USA and the UK (though my research focuses on the USA) have witnessed an acceleration of a long-term trend - the commercialisation of what is defined and redefined as intimate life. Most visible in upper middle class family culture, this trend now ricochets into low-end commercial enterprises and, via television, throughout society as a whole.

\section{Forces behind the commercialisation of intimate life}

The arrow of the market can point forward or back, but at the moment it is facing forward in the arena of intimate life, due to a confluence of trends - in the workplace, the service mall and the family.

Firstly, over the last 30 years in the USA and much of Europe, the realm of work has absorbed more people and absorbed them for longer periods each year. The majority of US women are now in paid work and for many in both the professional and working class, the workday has grown longer.

In addition, a number of corporations - highly untypical of most companies, but seen at the professional core of US capitalism - have engineered a work culture that serves as a lure to work long hours. At Sun Microsystems in Sunnyvale, California, for example, workers wear casual clothes to work, nap in pup tents, work out at the company gym, drink cokes out of the office fridge, feed their goldfish and even bring their dogs to work (Useem, 2000).

The working class goes daily to jobs - many of them jobs in the 'service mall' as maids, childcare and elderly care workers - without such workplace lures. These jobs form the basis of another kind of overtime culture. Here, the jobs to be had go with low pay, forcing both parents to work and forcing some workers to take up two, sometimes three jobs. For what disposable income they have, parents here also face commercial substitutes for life at home: unlicensed family childcare, overcrowded nursing homes, Chuck E. Cheese birthday party set-ups, McDonald's family dinners. 
The second force pressing for commercialisation is this service sector which markets itself as needs substitutes which can pick up the tasks desperate working parents are forced to drop. Some of these are an extension of services that have become familiar - maid services, nannies, day care and care for the elderly. Others fill new, often specialised niche needs - speed-dating services, parental role evaluation, family photo album assembly, party animation services.

The third force is composed of trends within the family. Like many modern cultures, the USA has witnessed a lower birth rate and a rising proportion of adults who are single or divorced, some of whom are elderly people living on their own. The culture of 'home'

- while ever more vital to people to retain and develop - is also becoming a prime target for marketers offering to make places 'feel like home'. In short, trends at the workplace, in the service-mall and in family life each in their way press the market into 'private life'.

\section{The culture of outsourcing}

In 'Outsourcing: having it all but not doing it all', Sandholtz et al. (2004) give us their understanding of this outsourcing culture. They describe a management consultant named Chris Watson, who travels around the world, and volunteers as a youth group leader at her church and outsources cooking, cleaning, laundry and even the locating of dating prospects. As she says, "I've found that I can hire someone to do almost anything I don't want to do myself... Mingling at clubs or parties isn't a great use of my very limited social time”. To the authors, Chris Watson applies to herself a principle that business applies to itself: specialisation and comparative advantage. As they write,

\footnotetext{
“ Chris belongs to one of those groups we call 'outsourcers' - people who are so clear about their personal priorities that they hire out almost everything else. Outsourcing has worked its way into business lingo as corporations have slashed costs and focused on their core competences - the things they're best at and that make them distinctive. Everything else is turned over to vendors. Individuals have taken the same approach as they try to control their overstuffed lives. They farm out certain tasks and obligations to focus more attention on the activities, relationships and causes they care most about." (2004, p.1)
}

But how does outsourcing parts of yesteryear's family roles impact our feelings about intimate life? The term 'outsourcing' suggests that something inside the home is being taken outside it. What outsourcing does, in fact, is to import cultural images and strips of rhetoric from somewhere outside the home into it. Responsibility for the task goes out. Newcomers with their own notions - attached to their own psychological projections - of a 'real need' and a 'good home' come in.

While outsourcing can bring work culture into the home that is distinctly not homey, it can also bring into the home something more complex - a market-laundered version of hominess. It brings home 'back' home. An example of the first would be Family 360, a new service described by the New York Times Magazine as one of the 99 hot new ideas of 2002. Designed by a management-consulting firm called LeaderWorks based in Monument, Colorado, the programme offers 'personalised family assessments' to executives at such corporations as General Motors, IBM, Goodrich, Honeywell and Dupont. Based on 'Management 360', a widely used programme for evaluating executives at the workplace, 'Family 360', remarkably, offers to evaluate a client's performance as parent and spouse at home (Tough, 2002). As the journalist Paul Tough describes the service:

“ The Family 360 process starts with the executive's spouse, children and in some cases his parents and siblings filling out a detailed questionnaire in which they evaluate the subject both quantitatively scoring him from 1 to 7 on, say, how well he 'helps create enjoyable family traditions' and 'uses a kind voice when speaking' - and qualitatively listing 'three to five positive attributes' and 'two things you want this person to do less'. The data are then analysed by LeaderWorks, and the results are sent to the executive in a 'growth summary' report that presents his family's concerns in the form of bar graphs and pie charts and identifies 'focus areas' for such things as 'paying special attention to personal feelings', and 'solving problems without getting angry'.” (p.65)

Consultants interview the worker's spouse, children, other relatives, and people who see him or her from every vantage point - hence the term, '360'. LeaderWorks personnel then meet with the family to create a 'Development Plan to Strengthen Family Relationships', and to suggest follow-up services for later on. As Tough notes, the company also provides: 
“. . . an investment guide with hundreds of specific actions that let you connect with your family as efficiently as possible: buy a speakerphone for the home so you can join in on family game night when you're on the road; go for a walk with your child every day, even if it's only to the end of the driveway; create 'communication opportunities' while doing the dishes with your spouse or waiting in line with your child at the store.”

The Process can help you identify the "high leverage activities that will mean the most to your important relationships". In a web-based promise of a free, quick, report on work-life's best practices, the applicant is asked to answer such questions as, "if you have children, what specific actions have you taken to teach values, encourage contribution or create memories?” (Hochschild, 2004) ${ }^{2}$

Family 360 offers an office-like approach to family life. Other services offer a market version of cosiness, intimacy, a sense of 'really being at home' - what, curiously, might have been there anyway if it hadn't been missing or taken out, often by over-work, television-viewing and shopping.

Internet ads for services offer to take over familiar family tasks - care for children, the elderly, cooking, cleaning, of course, but also specific tasks - cleaning out one's closet, writing letters to friends, locating a soul-mate. Most such ads appeal to potential clients by offering to take off their hands chores they don't want to do. As one ad temptingly reads 'Not enough time? Let me help out ... Maybe dinner is too much after a hard day's work. I could make you a wonderful coconut curry while you are at work and have it on the table when you arrive'. Other ads offer to organise your 'home/ things/papers clean house/minor repairs, shop for personal items or gifts'. One internet ad for a personal assistant offers to 'do personal shopping, coordinate holiday décor and oversee the design and mailing of holiday cards'. Another offers to 'organise your closet' to 'manage the family calendar' and to 'assemble photos in your family photograph album'. Other ads offer to 'assist with email'. Both service providers and clients 'move the wall'. That is, while the difference between paid and unpaid life remains, the meanings associated with each shifts. What once seemed too personal to pay a person to deal with now doesn't seem that personal after all.

As Jacqueline Salmon, a reporter who wrote a story on such services in the Washington Post described it:

“ Brent Lloyd . . . is glad he turned over a hundred years worth of family photos stuffed in shoe boxes and crumbling scrap books to Marilyn Anderson, the owner of Creative Memories in Fairfax Station. Six weeks later, for about $\$ 600$, Lloyd got back three photo albums with descriptive captions and decorative touches, one for his elderly mother and two to share with his wife and three children." (Salmon, 1996, p.A1)

Brent Lloyd doesn't want to sort through his family albums. Others would consider it strange to see the handwriting of a stranger under that picture of Uncle Frank and Cousin Martha, or to know that a stranger's judgment had determined which photos were included and which not. Still other services raise this question of what's 'too meaningful' to outsource. One service organises children's birthday parties, making out invitations ('Sure hope you can come...') as well as providing party favours, entertainment, a decorated cake and balloons. Another service, Virginia-based Precious Places helps parents decorate their children's rooms. Creative Memories puts family photos in albums.

Another ad entitled 'Companion for Elderly' reads 'are your parents in a retirement home? Would you like to go out with them for a walk, stop by for a coffee or tea but you do not have the time? I can spend quality time with your elderly family member'.

The employer, the worker with the elderly grandmother - each of these parties develops a new relationship to their feelings. Each checks to see what 'feels right', under the new circumstances. Each tries to feel what they think they should feel, and each may live with some strain between what they deem they should feel and what they glancingly know they do feel.

I interviewed a man who ran a maritime funeral service for bereaved clients, to spread the ashes of loved ones on the ocean. The skipper of the boat explained that on a quarter to a third of his trips carrying ashes out to sea, relatives did not accompany him. If they did accompany him, he said, he poured the ashes from a cardboard box in the cabin of the launch, into a china urn which he placed on a table, draped with a velvet cloth. He then dropped nasturtium blossoms into the water before pouring the ashes overboard in the water. He said,

“ The flowers make it nice. If the relatives are there, I enjoy dropping the flowers as part of the ceremony. If they aren't, I drop them anyway, just to see what way the tide is flowing, because I don't want the ashes to float to the side of the boat. I sort of participate in the feeling when they're there, not so much 
when they aren't.”

Does the man try to hold the sacredness of the ashes in his mind? If he is reminded of loved ones he has himself lost, or if he is worried about something else - his boat, his income, his marital problems - what kind of emotion work does this mindfulness involve? A symbolic task is outsourced to him. That means that, in a sense, a certain feeling goes with the doing of the task. But how is one to interpret this feeling, and how link it to the task? On which side of the wall does the 'core' of the symbol lie - in the relative's participation in the ritual (itself unpaid) or in the fact that the ashes were spread (a task that can be paid for and symbolically be set out of the way)?

A growing culture of outsourcing deals with such questions of meaning - often through humour. Recent New Yorker cartoons capture a certain commercial - familial edge. One shows a mother and father wearing faces of impartial wonder at their son who has just pulled the tablecloth off the dining room table, breaking dishes and cups. The caption reads, 'Just wait 'til your nanny gets here.' In another, a father dressed in a business suit has given a birthday present to his son, and the son says, 'Tell your personal assistant I like my present very much.' Such humour taps our anxiety about outsourcing 'too much', tacitly establishing a boundary beyond which outsourcing is ridiculous. It reassures us that the wall is here, so to speak, and not there.

But serious questions remain about the juncture between commercial and intimate life. How do we tell the difference between expressions of emotional bonds that feel real, deep, whole and those that feel sloughed off, partial or fake? Is the boy really more grateful to his father's assistant than to his father? If so, what does the father feel? What does he think he should feel? What does the boy feel, and think he should feel? And the assistant?

Every day, the trend toward a commercialisation of intimate life challenges the very boundaries between personal and impersonal moments. The wall between paid and unpaid is changing its relation to the distinction between what seems to us personal and impersonal. We need to think further about his, but how?

\section{Thinking about commercialisation}

Three schools of thought deal with the interface of family and market life, and each approach or would approach this question in different ways. One would see it as part of an almost evolutionary march of history. Such thinkers as Talcott Parsons would focus - not on the market, or profit motive, or medium of money per $s e$ - but on the overall trend toward modernisation, a move from simple to complex, from less division of labour to more of it. In this perspective, the artisanal family progresses to a post/modern one - specialising in adult intimacy and the raising of children and when possible gradually outsourcing everything else (Parsons and Bales, 1955). Because domestic outsourcing fits modernisation and because modernisation is not, in this view, a problem, outsourcing seems natural. It arouses little curiosity. The march-of-history perspective sheds little light on these culture-driven moves that render us less, not more commodified. Through the course of history, some activities that used to be paid for now are not. In 18th-century Europe, for example, many upper class women sent their children to villages in the countryside to be breast-fed for a fee (Barnett and Marshall, 1992; Barnett et al., 1992; Burley, 1991). ${ }^{4}$ Today, our cultural ideas about children and the mother - child bond make such a thing unthinkable.

A second line of thinking focuses not on the grand march of history but on the wondrous cultural pageant resulting from various collages of market and non-market culture. In the Social Meaning of Money, Viviana Zelizer (1994), for example, beautifully illustrates the many ways we achieve personal ends through what would seem like impersonal means - paying money - through, for example, adoption, allowances, alimony, inheritance and gifts. Like the 'march of history' thinkers, Zelizer does not posit a market 'encroachment'. From the dawn of history, the idea is, we've had markets, so there is little here that is new or a problem. Zelizer's notion of market is closely linked to the use of money, and not to the profit motive, or to companies based on it. In my view, Zelizer brilliantly analyses aspects of social life inside capitalist economies (see also Nippert-Eng, 1996), ${ }^{5}$ without linking it to the principle that runs the system - the pursuit of profit. ${ }^{6}$

A third line of thinking does, though it omits some other things. Indeed, it focuses on businesses seeking new markets in many areas of life. Starting with Marx, such theorists express admiration for the great capacity of a free market system to produce and distribute goods and services. However, mindful of the limits of the profit motive in achieving the good of all, they keep a nervous eye on market expansion into every 
arena

- including that of intimacy. They have focused on the destructive use of natural resources (Schor, 2004; Schor and Holt, 2000) and human resources (Ehrenreich, 2001), the new inequities caused by privatisation of public functions (Kuttner, 1997) and the erosion of the commons (Bollier, 2003; Rowe, 2002).

In The Great Transformation, Karl Polyani argues that during the 19th-century, Europe changed from being a society with marketplaces, to a marketplace within which there are small societies. The market ripped free of 'society', he argued, and from a system of traditional obligations for the needy - a system for which the modern state would have to substitute.

Following Polyani, in the book Everything For Sale, the economist Robert Kuttner (1997) argues that when companies beholden to stockholders take over services everyone needs - schools, hospitals, transport those most in need lose. For-profit hospitals will drop the sickest patients; for-profit schools, the poorest students; for-profit nursing homes, the neediest elderly. The aim of business is to make money, not help the needy, but the needy, he rightly notes, still need help.

Not simply the student, the poor or the ill but all of us, David Bollier argues in his book, Silent Theft, are part of the encroachment of the market on the commons. Bollier, makes a case against for-profit companies taking over the free exchange of information on the internet, and the for-profit companies engaging in genetic research so as to sell genes (Bollier, 2003; Rowe, 2002).

In a similar vein, the economist Juliet Schor critiques the growth of consumerism for its overuse of the world's resources. We all benefit from our natural commons - that is, the earth itself, she observes. But as they extend to the globe, the twin headless horsemen - profit seeking companies and commodity hungry customers - pose an under-explored threat to the environment.

Finally, in The Age of Access: The New Culture of Hypercapitalism Where All of Life is a Paid-For Experience, Jeremy Rifkin (2000) makes, in very broad strokes, a critique of the fake culture of malls and planned communities now replacing historically-rooted communities and neighbourhoods (Fevre, 2003; Hochschild, 1997).

In my view, we are still in the midst of Polyani's 'great transformation', but the costs of it are more widespread, far more subtle and difficult to grasp. By focusing on the most powerful institutions of our time for-profit companies - I think the encroachment theorists - Polyani, Kuttner, Schor, Bollier, Rowe, Rifkin help us focus on the big picture. They lift capitalism, as a specific system, out of a more general concept of modernisation and hold it there. This is an important starting point. They don't explain why so many of us yearn for what commodification offers - from coconut curry soup to birthday party planners. They are missing some conceptual tools we need to illuminate what remains - especially in Rifkin's intriguing work cursory hunches about cultural degradation. In Zelizer and Nippert-Eng's work - their concepts of boundary work and bridges between zones of life, for example - we find some such tools.

But none of these schools of thought really ask how we know when something feels saleable or not. How do we cast a halo around certain events and not cast it around others? Seeing a child take its first breath, take its first step, seeing a casket lowered into a grave - at what points do we locate our notion of the sacred? And how is our idea of the sacred related to our idea of what can be for sale? What is it unthinkable to sell or buy? What do we feel at the various boundaries we set to commerce? These questions lie ahead.

\section{Saying I love you; personal meanings and emotion work}

The market has become, for most of us, a third party in our intimate relationships. Like the woman who compared herself to a worker at a bed and breakfast inn, we often pin an ear to the wall between market and non-market life, to gain our sense of meaning. We borrow across the wall. We jump over it and sometimes jump back. Starting from this premise, and drawing from it - the march-of-history, cultural-pageant and market-encroachment thinkers - we can finally ask how it is we say I love you in market society, and ask how we use our feelings to tell us we 'know'.

Before we were a market society, misery and disappointment and missed connections occurred in old-fashioned ways. A person failed to visit. A pie was not thought of, not baked, or baked badly and the recipient thereby got - or was at least given - a negative message. Gifts were made, and the meaning resided in the failure to make them. The same held true for activities. A child didn't invite an elderly parent to live with him or her, or visit. A father neglected his child. These were pre-market ways of saying 'I don't care'.

In much of the USA today, the market - in its most recent, rationalised, bureaucratised incarnation - has 
encroached and has changed this. It has introduced proxies, standardisation and commodification. Today, more people say 'I love you', by paid proxy. The one who thinks of giving and who pays for the giving is not the actual giver. The mind, heart and pocketbook of a gift are less and less the hands of it. I grow flowers to give to a friend. But then, I don't have the time or place to grow flowers. I buy them to give to a friend. But then I don't have time to shop for them, so I wire them. Similarly I make a cake for my child. But then I don't have time and the store cake looks and tastes better. So I shop for and buy the cake. Then I don't have time to shop, so I order the cake for the birthday, along, now with - if I can afford it - the birthday planner. I share authorship of the act. It is not just a me-to-you thing.

Second, the expression of a gift, a service, or object are usually standardised, generic. The birthday planner may offer her customer the 'Winnie the Pooh' birthday, or the 'Harry Potter' birthday, but the menu itself is standardised. The consultants of Family 360 give a man an evaluation of his performance as a father. They evaluate his performance, but the idea of conceiving of fatherhood as a performance that needs to be evaluated by business professionals, the list of high-leverage activities, this is itself standardised. 'Rent A Mom' helps clients plan their weekly menu and clean their bedroom bureau drawers. The linguine planned, the bras and underpants discarded, these are personal items. But the procedures by which they are planned or discarded are applied in a standardised way to all clients.

Finally, Rent-a-Mom and other such businesses are based on fee-for-service. Paying money and being paid money - this transaction - offers those on both sides of the deal flexibility. The deal is as permanent or temporary as the money is. On the one hand, this flexibility is the great appeal of the market; the customer gets what he needs and doesn't have to pay for what he doesn't need. The corporation, too, can withdraw from bad customers and move to good ones. On the other hand, when we commodify personal services we draw them into a framework of present time tit-for-tat deals. We withdraw them from history. As Georg Simmel long ago noted, the market introduces both the potential for freedom and estrangement. But what ratio of freedom to estrangement do the prevailing ideologies and practical conditions make people come to want or need? This question remains to be answered.

In short, through the use of proxies, standardised procedures and fee for service, personal services - as a way of saying 'I love you' - raise questions we address every day. What is personal? What is too personal? What isn’t personal enough? Looking at the impact of industrialisation on 19th-century England, Marx observed how workers could become alienated from both the products they made, and from those they bought. In the 'fetishism of commodities', we focus, Marx observed, on the commodity itself and forget the larger contexts in which it originates.

Here we explore a possible fetishism of services whereby the customer is invited to focus on the service itself apart from its larger context. The Family 360 client focuses on the 'family memory' package itself, but not on the process by which a father, with the aid of a paid consultant, comes to make the family memory, or indeed on what he actually remembers about making the memory. How does the service provider feel? And how does a child experience the self-consciousness threaded into the process of doing something together in order to remember it?

\section{Feeling rules and emotion work}

In everyday life we are often called on to manage our emotions - that is, to evoke or suppress feelings according to our sense of what we 'ought' to feel (Hochschild, 1983). However, the commercialisation of intimate life places a new kind of call on us to manage our emotions. We feel one way about the location of the 'wall' between market and non-market life. But we may actually be in another place vis à vis that wall. For example, we may not want to, or feel it 'right' to place an elderly parent in a nursing home and pay for the service of a proxy caregiver. Our feeling rules puts us on the non-market side of the wall while circumstances force us onto the market side. Maybe we don't like it but Grandma has to go. Or maybe the elderly parent and child both clearly want a good nursing home, but can't afford it. In either case, how we imagine acts to symbolise love may not accord with what we're able to do, or honestly feel like doing. We may be living on one side of the commercial wall, while our feeling rule resides on the other.

Increasingly, it seems, time has become less the language of love and the spending of money more so. This transition has allowed more room for us to de-symbolise one line of action as a sign of love, and re-symbolise another. But we know so very little about the emotional intricacies of this moving of the 
symbols.

A client who has placed a parent in a nursing home may come to symbolise his love as 'managing the care giver'. That is, a middle-aged child may displace his symbol of love from 'taking daily care of mother myself ', to managing the hired caregiver at the nursing home. This can create problems for the caregiver, who may now resent the man's repeated complaining calls about her care of his mother. She may see him as ungrateful or distrustful. For her part, the elderly patient may go willingly to the nursing home, not wanting to be a burden and not wanting to live alone or with family. Or she may feel 'warehoused' in which case only living back home would symbolise love. Whether as givers, proxies and receivers, people often sense some contradiction between a desire to give a personal gift and the impersonal means by which it is given.

So, from each vantage point, we often try to put a personal element back in. In so doing, each party has to move the symbols. The mother who might in a different decade symbolise her love of her child by making, with the child, a birthday cake, now symbolises her love by 'enjoying the cake' provided by the party service with the child. If a mother might once have devised party games, her symbol of love is now to co-consume ideally, to enjoy - the party. Or - if a photographer is not hired - she may take photographs of the child's enjoyment and in this way symbolise her love.

A busy working mother living in a marketised subculture but holding onto a pre-market view of birthday parties, might feel 'I'm not doing enough' and try to manage feelings of guilt. Or she might displace her anxiety about not doing enough herself by anxiously monitoring the elder care worker or the Chuck E. Cheese waitress. Or she might envy those with enough money to commodify life more, but feel she shouldn't envy them, because after all they've become estranged from the important things in life. So she does envy work.

So, for the modern market person, the meaning or fun is not in the growing of a vegetable garden but in the eating from it. The fun is not in building the house but in living in it. The fun is not in the training of the dog but in having a trained dog. It's not only that we can't grow vegetables, build houses or train dogs, but that we have ceased to look for meaning there. We've moved our personal symbols from production to consumption, but which do we leave back in the realm of production and which not?

The child, too, must look for an expression of care where it now is. Does a child feel hurt or disappointed that mother wasn't in the kitchen making a cake today? Or didn't spend the time to think up fun games together? Does an elderly person feel like 'a burden' when others are paid to talk to her? Or does she feel that the thought to hire someone, the money to pay them was itself the gift. The recipient here too does emotion work. Is the child grateful to the parent for her money? For compliance to a wish? For co-enjoying the occasion? Or does a child really feel the parent is 'getting out of really giving me something' but tries to feel grateful anyway?

Finally, the proxy does emotion work. How personal or impersonal is the task, for the Rent a Mom, of cleaning a bedroom bureau? Does the maritime funeral service worker feel, as he drops the nasturtium buds on the water before dropping the ashes of the deceased there, 'there goes the ashes of a person who once lived, like I?' Or 'there goes a nasturtium?'

To sum it up, the wall between market and non-market life is permeable; what we're doing on one side of it we often compare to what we could be doing on the other. But in addition, our feelings about the wall have themselves shifted with time. In the USA over the last 30 years, various trends have jointly pushed us in the direction of commodifying intimate life. This raises many intriguing questions for those interested in organisations and emotions, bearing on the emotional relationship between each of us and capitalism. For this relationship infuses itself into virtually all other relationships, via our connection to the premises of capitalism as they play out in everyday life. It raises the question of what we hold important or sacred and how we hold it so.

What happens, we may silently wonder, when we lose our holds in a capitalist system - our job, our pay, our ability to buy goods and services - and with these the passport to the symbols of love? Even when we have our hold in it, we can ask ourselves how much love depends on money. We take the measure of a commercial age within the magnified moments of our dearest relationships. We discover, too, what would stand firm outside it. 


\section{References}

Barnett, R.C. and Marshall, N.L. (1992) 'Worker and mother roles; spillover effects and psychological distress', Women and Health, Vol. 18, No. 2, p.9.

Barnett, R.C., Marshall, N.L. and Sayer, A. (1992) 'Positive-spillover effects from job to home: a closer look', Women and Health, Vol. 19, Nos. 2-3, p.13. Bollier, D. (2003) Silent Theft: The Private Plunder of Our Common Wealth, New York and London: Routledge.

Braverman, H. (1974) Labor and Monopoly Capitalism, New York: Monthly Review Press. Burley, K.A. (1991) 'Family-work spillover in dual-career couples: a comparison of two time perspectives', Psychological Reports, Vol. 68, No. 2, p.471.

Ehrenreich, B. (2001) Nickel and Dimed: On (not) Getting by in America, New York: Metropolitan Books.

Fevre, R. (2003) The New Sociology of Economic Behaviour, London: Sage.

Fineman, S. (2003) Understanding Emotion at Work, London: Sage.

Hochschild, A.R. (1983) The Managed Heart: Commercialization of Human Feeling, Berkeley and Los Angeles: University of California Press.

Hochschild, A.R. (1997) The Time Bind: When Work Becomes Home and Home Becomes Work, New York: Metropolitan Books.

Hochschild, A.R. (2003) 'The commodity frontier', in: The Commercialization of Intimate Life: Notes from Home and Work, Los Angeles and Berkeley: University of California Press.

Hochschild, A.R. (2004) 'Through the crack of the time bind: from market management to family management', in: M.H. Jacobsen and J. Tonboe (Eds.) The Work Society? The Seizure of Time and Fractured Identity, Copenhagen: Reitzels Publishing House (in English, in a Special Issue of Sociological Research, Vol. 72, No. 1 (Spring, 2005)), in press.

Hyde, L. (1983) The Gift: Imagination and the Erotic Life of Property, New York: Vintage Books. Kuttner, R. (1997) Everything for Sale: the Virtues and Limits of Markets, New York: Alfred A. Knopf.

Lasch, C. (1977) Haven in a Heartless World, New York: Basic Books.

Linder, S.B. (1970) The Harried Leisure Class, New York: Columbia University Press.

Mauss, M. (1967) The Gift: Forms and Functions of Exchange in Archaic Societies, New York: Norton.

Merleau-Ponty, M. (1964) The Primacy of Perception, and Other Essays on Phenomenological Psychology, the Philosophy of Art, History and Politics, J.M. Edie (Ed.), Evanston, Illinois: Northwestern University Press.

Nippert-Eng, C.E. (1996) Home and Work: Negotiating Boundaries Through Everyday Life, Chicago: University of Chicago Press.

Parsons, T. and Bales, R.F. (1955) Family, Interaction and Socialization Process, Glencoe, IL: Free Press.

Polanyi, K. (1957) The Great Transformation: The Political and Economic Origins of Our Time, Boston: Beacon Press, 1944.

Rifkin, J. (2000) The Age of Access: The New Culture of Hypercapitalism Where All of Life is a Paid-For Experience, New York: Jeremy P. Tarcher/Penguin.

Rowe, J. (2002) 'The promise of the commons', Earth Island Institute, Fall, Vol. 17, No. 3 , pp.28-30.

Sahlins, M.D. (1972) Stone Age Economics, New York: Aldine de Gruyter Publishers.

Salmon, J. (1996) ‘For hire: helpers for harried parenting', Washington Post, September 17, P.A1.

Sandholtz, K., Derr, B., Buckner, K. and Carlson, D. (2004) ‘Beyond juggling, rebalancing your busy life’. Available from: http://businessknowhow.com, 'Growth and Leadership'. Schor, J. (2004) Born to Buy: the Commercialized Child and the New Consumer Culture, New York: Scribner.

Schor, J. and Holt, D.B. (Eds.) (2000) The Consumer Society Reader, New York: The New Press.

Useem, J. (2000) 'Welcome to the new company', Fortune, January, pp.62-70.

Zelizer, V.A. (1994) The Social Meaning of Money: Pin Money, Paychecks, Poor Relief and Other Currencies, New York: Basic Books.

Zelizer, V.A. (1996) 'Payments and social ties’, Sociological Forum, Vol. 2, No. 5, pp.481-495.

Zelizer, V.A. (2000) ‘The purchase of intimacy’, Law and Social Inquiry, (Fall) pp.817-848.

Zerubavel, E. (1991) The Fine Line: Making Distinctions in Everyday Life, New York: Free Press. 


\section{Notes}

${ }^{1}$ What are now called 'new company towns' also offer many paid services that a homemaker or the man of the house used to do at home - at work: laundry and dry cleaning service, carwash and maintenance, and chef-cooked dinners. Even civic life has come to work. Lands End, a mail order clothing company and Amgen, a biotech firm, have developed employee clubs for 'chess, genealogy, gardening, model airplanes, public speaking, tennis, karate, scuba diving and charity.' Another corporation has a singles group called Mingle. According to Useem, a thousand companies nationwide offer on-site Bible study groups. With the mall and civic life brought in the door of the workplace, the professional and managerial worker tends, of course, to work long days and have less time to live the non-work side of life. Paul Tough 'Dad's Performance Review' a sub essay (p.65) in a larger essay entitled 'The Year in Ideas’, pp.80-82. The New York Times Magazine, December 15, 2002. The premise behind this service is that the executive can be as efficient at home as he is at work, with no loss - indeed, a gain - to family life. Indeed, as the Web description for Family 360 notes, 'The Family 360 Process is a way to assess how you are doing with the precious time you have to build and strengthen your important personal relations.'

${ }^{3}$ With modernisation, Parsons argues, the family has moved from an institution that performed many functions (education, entertainment, economic activity, socialisation, procreation) to one that performed few. The factory system took over economic activities, schools and summer camps, education, and so on.

The market itself is welded into a notion of modernity. Meanwhile families are matters of role differentiation between male and female roles, in Parsonian theory, and matters of role-overload or role-spillover in later formulations. The hostess who compared herself to a worker at the bed and breakfast inn might be said to be suffering from 'role overload'.

5 Christina Nippert-Eng (1996), focuses on ways we draw boundaries between symbolic realms of home and work - by putting up family photos at work, placing keys for home and work on the same key-chain, using the same or separate calendars for home and work events, keeping one or two telephone books for colleagues and friends. Some people, she notes, use integrating, others use segmenting strategies. Applying this line of thinking, we might notice how a father under the tutelage of Family 360 evaluators, might categorise the 'memories he tried to create' to improve his score in memory creation, from memories that simply evolve. This perspective does not point us, however, toward any link between such observations and a company's motive in developing markets for the overworked.

6 As Ralph Fevre has argued (2003), economic sociology that once launched a major critique of Weber's 'iron cage' have quietly climbed inside it to study and comment on it 'from within'.

${ }^{7}$ Marx both admired and faulted capitalism. His major concern, of course, was with the owners' exploitation of workers, the growing class divide between rich and poor and the individual's alienation both from what she makes and from what she buys.

As advertisers pitch their TV ads to children of younger and younger ages, it inspires materialism which she found to be linked to depression in the school children she studied for her book Born to Buy (2004).

9

Many services are advertised in such a way as to invite us to question the adequacy of who we are or what we have. Is a birthday actually more relaxing and fun if someone else does the planning and work? Is a marriage actually more exciting, harmonious, passionate with the aid of a marriage coach? Is Christmas dinner more tasty at the restaurant? Just as the ads for skin products feature young women with peaches and cream complexions, so ads for personal services raise the bar on personal fulfillment almost out of reach. (Thanks to Mark Kramer for this thought.) 